\title{
INSULTĄ PATYRUSIŲ PACIENTŲ KOGNITYVINIŲ FUNKCIJŲ, DEPRESIŠKUMO IR SAVIVEIKSMINGUMO YPATUMAI
}

\author{
Jovita Janavičiūtè, Liuda Šinkariova \\ Vytauto Didžiojo universiteto Socialiniu mokslu fakulteto Psichologijos katedra
}

Raktažodžiai: insultą patyrę pacientai, kognityvinès funkcijos, depresiškumas, saviveiksmingumas.

\begin{abstract}
Santrauka
Insultą patyrusių pacientų grupe yra specifinè imtis, kuriai būdingi ịvairūs insulto sukelti padariniai, sunkinantys kasdienį funkcionavimą: kognityvinių funkcijų sutrikimas, depresiškumas, sumažèjęs saviveiksmingumas. Darbo tikslas - įvertinti insultą patyrusių pacientų kognityvinių funkcijų, depresiškumo ir saviveiksmingumo ypatumus. Tyrimo objektas ir metodika. Tyrime dalyvavo 22 insultą patyrę pacientai. Amžius nuo 61 iki 89 metų $(\mathrm{M}=78,09 ; \mathrm{SD}=8,6)$. Tiriamiesiems buvo pateikti socialiniai ir demografiniai klausimai. Insultą patyrusių pacientų kognityvinès funkcijos matuotos naudojantis Adenbruko kognityvinio tyrimo metodika (III versija). Depresiškumui matuoti naudotas Paciento sveikatos klausimynas, saviveiksmingumui - Saviveiksmingumo klausimynas insultą patyrusiems pacientams. Tyrimo rezultatai atskleidè, kad 81,8 proc. insultą patyrusių pacientų patiria kognityvinių funkcijų sutrikimus, 63,6 proc. būdingas depresiškumas. Insultą patyrę pacientai pasižymi gana aukštu saviveiksmingumu.
\end{abstract}

\section{Ivadas}

Galvos smegenų insultas dažniausiai paveikia žmogaus kognityvines funkcijas. T. K. Tatemichi ir kiti (1994) išskyré insulto sukeltą kognityvinių funkcijų pablogejjimą, kuriam esant smarkiai sutrinka demesys, atmintis, kalba, orientacija, vizualinis erdvès suvokimas bei abstraktusis mąstymas. Kognityviniu funkcijų: atminties, demesio ir vizualinio erdvès suvokimo sunkumai pasireiškia $30-50$ proc. insultą patyrusių pacientų [2]. Kiti autoriai [3] nurodo dar didesnị kognityvinių funkcijų pablogėjimo mastą, kuris svyruoja nuo 20 iki 80 procentų. Statistika atskleidžia, jog insultą patyrusių pacientų kognityvinių funkcijų sutrikimų mastas yra didelis, lemiantis neịgalumo didejjimą, kuris tampa našta ne tik asmens, bet ir visuomenès lygmenyje [4]. Insultą patyrusių pacientų ko- gnityvinių funkcijų sutrikimų paplitimas Lietuvoje neaiškus. Tyrimai, nustatantys insultą patyrusių pacientų kognityvinių funkcijų sutrikimų mastą, prisidètų atskleidžiant šiai grupei būdingus ypatumus.

Nustatyta, kad po insulto išsivysto depresija, kurios paplitimas šioje pacientu grupeje yra didelis [5]. Poinsultinè depresija, kaip insulto sukeltas sutrikimas, yra žinomas seniai. Vieni pirmujų autorių, pradejusių skelbti duomenis apie ši sutrikimą, buvo F. M. Folstein, R. Mailberger ir R. P. Mc Hugh (1977), kurie pastebejjo, kad insultą patyrusiems pacientams dažniau būdinga depresija, nei sergantiesiems artrologinemis ligomis. To paties tyrimo metu gauti rezultatai atskleide, kad nuotaikos sutrikimai yra labiau specifiška insulto komplikacija, nei reakcija ị judèjimo negalią. Vèlesnių metų tyrimais nustatyta, kad poinsultinè depresija būdinga daugiau nei trečdaliui insultą patyrusių pacientų, o per pirmuosius penkerius metus ji pasireiškia nuo 39 iki 52 proc. pacientu [7] ir yra dažniausia psichiatrinè insulto komplikacija [8]. Lietuvos mokslininkų tyrimuose tokių duomenu nepavyko rasti, todèl svarbu nustatyti, ar mūsų šalyje insultą patyrusių pacientų depresiškumas yra dažnas komorbidinis sutrikimas. Svarbu nustatyti ne tik paplitimo dažnį, bet ir depresiškumo intensyvumą. Tokios žinios teiktų galimybę palyginti mūsų šalies tyrimus su užsienio mokslininkų šios srities tyrimais. Nors autoriai pateikia didelị depresiškumo ir netgi klinikinès depresijos paplitimą šioje tiriamujų grupeje, tačiau šie simptomai išsivysto ne visiems pacientams. Užsienio tyrejjai pateikia įvairių prielaidų, analizuodami veiksnius, skatinančius depresiją arba saugančius nuo jos. Kalbant apie psichologinius saugos veiksnius, kaip vienas iš svarbiausių įvardijamas asmens saviveiksmingumas - pasitikèjimas savo jègomis sẻkmingai ịveikti užduotis. Insultą patyrusių pacientų didesnis saviveiksmingumas siejamas su mažesniu depresiškumu, geresne gyvenimo kokybe ir fiziniu bei kasdieniu funkcionavimu [9].

Saviveiksmingumas kaip reiškinys pradètas nagrinèti A. Banduros (1995) socialinèje kognityvinèje asmenybès teorijoje kaip vienas iš pagrindinių aspektų. Saviveiksmingumas 
apibūdinamas kaip pasitikejimas savo jègomis sėkmingai atlikti užduotį ar ịveikti susidariusią situaciją. A. Bandura (1995), nagrinèdamas elgesio pokyčius, padarė prielaidą, kad nuo saviveiksmingumo priklauso, bus inicijuotas ịveikos elgesys ar ne, kiek pastangų bus dedama ir kiek laiko bus dedamos pastangos tam tikrai sudetingai situacijai ịveikti. Nors rezultatas priklauso nuo galimo elgesio pasekmių, saviveiksmingumas siejamas su tam tikro elgesio kontrole, igalinimu. Asmuo, pasižymintis aukštu saviveiksmingumu, turi didesni savo veiksmų kontrolès jausmą, todèl rečiau įvykių pasekmes priskiria aplinkos įtakai. Tai atspindi tikejjimą savo jẻgomis kontroliuoti problemiškas aplinkybes, imantis adaptyvių ivveikos strategijų. Apibendrinant pateiktą informaciją, galima teigti, kad saviveiksmingumas yra labai svarbi žmogaus savybė, padedanti kontroliuoti savo gyvenimą. Ši savybè gali būti išugdoma ir stiprinama, todèl svarbu suprasti, koks yra insultą patyrusių pacientų saviveiksmingumo lygis. Kompleksinės žinios apie šių pacientų kognityvinių funkcijų, depresiškumo ir saviveiksmingumo ypatumus svarbios ne tik moksline prasme, bet pritaikomos ir praktiniame psichologo darbe, pavyzdžiui, sudarant insultą patyrusių pacientų individualius reabilitacijos planus, siekiant efektyvesnio sveikatos atkūrimo.

Mokslinès literatūros analizè atskleidè, kad klinikinių ir specifinių imčių tyrimuose dažnai nepakankama aprašomosios statistikos analizè, kuri padètų suvokti tai imčiai būdingus ypatumus. Šios žinios papildytų esamus statistinius insulto paplitimo duomenis, kurie iliustruoja sergamumo bei mirtingumo nuo šios ligos mastą, tačiau neatskleidžia pacientų klinikinių ir psichologinių sunkumų. Platesnis insultą patyrusių pacientų kognityvinių funkcijų, depresiškumo ir saviveiksmingumo ypatumų atskleidimas prisidètų prie geresnio tokių pacientų paplitimo ir sutrikimų lygmens supratimo.

Darbo tikslas - iqvertinti insultą patyrusių pacientų kognityvinių funkcijų, depresiškumo ir saviveiksmingumo ypatumus.

\section{Tyrimo objektas ir metodika}

Šis tyrimas yra projekto „Insultą patyrusių pacientų kognityvinio funkcionavimo ir emocinès būsenos sąsajos" (Nr. 09.3.3-LMT-K-712-16-0051), vykdomo pagal Lietuvos mokslo tarybos poveiklę ,Studentų gebejjimų ugdymas vykdant tyrimus semestro metu“, dalis. Tyrimui atlikti gautas Vytauto Didžiojo universiteto etikos komisijos leidimas Nr. EKL-2020.01.

Tiriamieji buvo kviečiami tikslinès atrankos būdu. İtraukimo ị tyrimą kriterijai: 1) insulto diagnozé; 2) gimtoji kalba - lietuvių; 3) ne mažiau kaip 2 dienas stacionare esantys pacientai 4) Protinès būklès trumpojo tyrimo (MMSE) re- zultatas - daugiau nei 15 balų. Pacientai, kuriems po insulto pasireiške sunkūs motorikos sutrikimai, afazija ar kiti neuropsichologiniai sutrikimai, galèję turèti įtakos tyrimo rezultatams, nebuvo kviečiami dalyvauti tyrime. Išsikeltam tikslui pasiekti atlikta kiekybinè tiriamujų apklausa. Tyrime dalyvavo 22 insultą patyrę pacientai.

Pirmiausia tiriamieji buvo supažindinti su tyrimo procedūra, jiems pateikiama informuoto paciento sutikimo forma, kurią buvo prašoma pasirašyti sutinkantiems dalyvauti tyrime. Apklausa pradèta nuo socialinès ir demografinès charakteristikos anketos, kurioje pacientai nurodè savo lytį, amžių, gyvenamają vietą, išsilavinimą, šeiminę padètį.

Kognityvinès tiriamujų funkcijos įvertintos naudojant Adenbruko kognityvinio tyrimo metodikos III versiją (angl. Addenbrooke's cognitive examination, sutrump. ACE-III) [11]. Atliekant šị testą, daugiausiai galima surinkti 100 balų. Kuo daugiau balų - tuo geresnès asmens pažintinès funkcijos. Šia metodika tiriamos penkios sritys: dèmesys, atmintis, kalbos sklandumas, kalba, erdviniai gebejjimai. Ši priemonè nemokama ir laisvai prieinama, tyrimas trunka apie $15 \mathrm{mi}-$ nučių [11]. Testas pasižymi aukštu jautrumu ir specifiškumu, gerais psichometriniais rodikliais. Insultą patyrusių pacientų imtyje siūlomas ribinis balas yra 82 [12]. Vilniaus universiteto taikomosios psichologijos laboratorija šią priemonę išverte ị lietuvių kalbą. Gautas leidimas ją naudoti. Šiame darbe ACE-III pasižymi aukštu vidiniu skalių suderinamumu (Cronbach $\alpha=0,84$ ).

Tiriamujų depresiškumas vertintas naudojant Paciento sveikatos klausimyną (angl. Patient health questionnaire, sutrump. PHQ-9) [13]. PHQ-9 yra išverstas ị lietuvių kalbą, nemokamas ir laisvai prieinamas. Anot K. Kroenke ir R. L. Spitzer (2002), tiriamieji, surinkę nuo 0 iki 4 balų, nepasižymi arba pasižymi minimaliu depresiškumu, surinkę 5-9 balus - nedideliu depresiškumu, 10-14 - vidutinišku depresiškumu, 15-19 - vidutiniškai sunkiu depresiškumu, o surinkę daugiau nei 20 balų pasižymi sunkiu depresiškumu. Šiame darbe klausimynas pasižymi aukštu vidiniu skalių suderinamumu (Cronbach $\alpha=0,75$ ).

Tyrimo dalyvių saviveiksmingumas matuotas naudojant Saviveiksmingumo klausimyną insultą patyrusiems pacientams (angl. The stroke self efficacy questionnaire, sutrump. SSEQ) [15]. SSEQ sudaro 13 teiginių, kurie yra specifiniai šios pacientų grupès saviveiksmingumui išmatuoti ir apima jų kasdienio funkcionavimo veiklas. Ši skalè pasižymi gerais psichometriniais rodikliais. Klausimynas tiria dvi insultą patyrusių pacientų saviveiksmingumo sritis [16]: aktyvumą ir savikontrolę. Šis klausimynas yra laisvai prieinamas ir nemokamas, o jị išversti i lietuvių kalbą ir naudoti buvo gautas autorių leidimas. Šiame darbe klausimyno aukštas vidinis suderinamumas (Cronbach $\alpha=0,83$ ). 
Tyrimo rezultatams analizuoti naudota aprašomosios statistikos analizè, kuri leidžia geriau suprasti turimus duomenis ir atskleisti imčiai būdingus ypatumus. Duomenų analizè atlikta naudojant IBM SPSS programos 21 versiją.

\section{Tyrimo rezultatai}

Tyrime dalyvavo 22 insultą patyrę pacientai: 11 vyrų ir 11 moterų. Tiriamujų amžius nuo 61 iki 89 metų $(\mathrm{M}=78,09$; $\mathrm{SD}=8,6)$. Daugiau nei trys ketvirtadaliai (77 proc.) tiriamuju gyveno mieste, o kiti (23 proc.) - kaime. 64 proc. tiriamujų turèjo vidurinị ir žemesnį nei vidurinị išsilavinimą, o 36 proc. - aukštesnį nei vidurinį. 45 proc. tiriamujų buvo susituokę, 41 proc. - našliai, o 14 proc. - išsiskyrę. Pacientu kognityvinių funkcijų įverčiai pateikti 1 lentelëje.

Tyrimo rezultatai atskleide, kad insultą patyrę pacientai pasižymi pakankamai geromis demesio, kalbos ir erdviniu gebejjimų funkcijomis. Insultą patyrusių tyrimo dalyvių atminties tendencijas atskleidžia suminis atminties įvertis, kurio vidurkis $14,45( \pm 5,05)$, kai maksimalus bendras atminties ịvertis gali siekti 26 balus. Iš visų suminių subskalių ịverčių, išskyrus bendrą ACE-III rodikli, didžiausias standartinis nuokrypis buvo atminties įverčio. Tokie rezultatai atskleidžia, kad tiriamujų atminties rodikliai skyrèsi. Tai patvirtina didelis minimalaus ir maksimalaus balų skirtumas. Iš gautuju rezultatų matyti, kad insultą patyrusių pacientų atmintis yra bloga. Bendras žodinio sklandumo suminio įverčio vidurkis yra 6,27, o maksimalus balas 11 , kai buvo galima surinkti 14 balų. Tai rodo, kad insultą patyrę pacientai pasižymi blogesnèmis žodinio sklandumo funkcijomis. Tyrimo rezultatai atskleide, kad bendras ACE-III ịverčio vidurkis buvo 68,41

1 lentelẻ. Tiriamujų kognityvinių funkcijų ivverčių ypatybės pagal ACE-III rodiklius

SN-standartinis nuokrypis.

\begin{tabular}{|l|c|c|c|c|}
\hline $\begin{array}{l}\text { ACE-III sričiŭ } \\
\text { suminiai įverčiai }\end{array}$ & $\begin{array}{c}\text { Vidur- } \\
\text { kis }\end{array}$ & \multirow{2}{*}{ SN } & \multicolumn{2}{|c|}{ Diapazonas } \\
\cline { 4 - 5 } & 15,27 & 2,03 & $12-18$ & $0-18$ \\
\hline 1. Démesio & 14,45 & 5,05 & $5-22$ & $0-26$ \\
\hline 2. Atminties & 6,27 & 2,62 & $2-11$ & $0-14$ \\
\hline 3. Žodinio sklandumo & 19,5 & 3,43 & $13-24$ & $0-26$ \\
\hline 4. Kalbos & 12,91 & 2,49 & $5-16$ & $0-16$ \\
\hline 5. Erdviniu gebejjimu & galimas \\
\hline $\begin{array}{l}\text { 6. Bendras ACE-III } \\
\text { ivertis }\end{array}$ & 68,41 & 11,82 & $45-87$ & $0-100$ \\
\hline
\end{tabular}

2 lentelè. Tiriamuju pasiskirstymas pagal ACE-III ịverčius, atsižvelgiant ị ribinị balą

\begin{tabular}{|l|c|c|}
\hline ACE-III ivertis & N & Procentai \\
\hline$<82$ balai & 18 & 81,8 \\
\hline 82 balai & 2 & 9,1 \\
\hline$>82$ balai & 2 & 9,1 \\
\hline
\end{tabular}

$( \pm 11,82)$. Nei vienas iš tiriamujų nesurinko maksimalaus galimo ACE-III suminio įverčio. Pasitaikè tiriamųjų, kurie surinko mažiau nei pusę galimo didžiausio suminio balo. Didelis standartinis nuokrypis rodo, kad tiriamujų surinkti balai yra nevienodi, o tai patvirtina mažiausios ir didžiausios surinktų balų sumos skirtumas. Taigi, insultą patyrę pacientai tarpusavyje skiriasi pagal kognityvinių funkcijų ypatumus, o prasčiausiai atliko atminties ir žodinio sklandumo užduotis (1 lentelè).

Lyginant pacientus pagal nustatytą ribinị kognityvinių funkcijų balą, nustatyta, kad dauguma ( 81,8 proc.) insultą patyrusių tyrimo dalyvių surinko mažiau balų, nei nustatytas ribinis ịvertis, 9,1 proc. pacientų surinko ribiniam ịverčiui priskiriamą balų sumą, o tiek pat tiriamųjų surinko daugiau balų, nei nustatytas ribinis ịvertis (2 lentelè). Galima teigti, kad didžiajai insultą patyrusių pacientų daliai būdingi kognityvinių funkcijų sutrikimai.

Vertinant insultą patyrusių pacientų depresiškumo ypatumus, tyrimo rezultatai atskleide, kad bendras PHQ-9 suminis ivverčio vidurkis yra $6,32( \pm 4,59)$. Tai rodo, kad tiriamieji pasižymi lengvu depresiškumu. Analizuojant duomenis pagal pateiktus PHQ-9 ribinius įverčius, rezultatai atskleidè, kad daugiau nei trečdalis (36,4 proc.) tiriamujų nepasižymi arba pasižymi minimaliu depresiškumu, o beveik pusei $(45,5$ proc.) būdingas nedidelis depresiškumas. Nedaugeliui (13,6 proc.) tiriamujų būdingas vidutinis depresiškumas, o 1 sunkus (3 lentelè).

Analizuojant tiriamujų saviveiksmingumo ypatumus, galima išskirti tik dvi sritis, kuriose vidurkiai buvo mažesni: vaikščiojimas ant bet kokio grindinio ir veiklų atlikimas. Patyrusieji insultą šiose srityse mažiau pasitikèjo savo jègomis, lyginant su kitomis sritimis. Suminiai ịverčiai parodè, kad insultą patyrę pacientai savo jègomis pasitiki atlikdami daugelị veiklos rūšių, palaikydami sveikimo procesą bei rūpindamiesi savimi. Pasitaike tiriamuju, kurie surinko mažiau balų, tačiau bendras insultą patyrusių pacientų saviveiksmingumo ịvertis yra pakankamai didelis.

\section{Rezultatu aptarimas}

Insultą patyrusių ir sveikų tiriamujų kognityvinių funkcijų ypatumų palyginimo rezultatai atskleidžia, kad kogni-

3 lentelè. Tiriamuju pasiskirstymas pagal PHQ-9 įverčius, atsižvelgiant ị ribinius balus

\begin{tabular}{|l|c|c|}
\hline PHQ-9 depresiškumo ịvertis & N & Procentas \\
\hline Nėra arba minimalus & 8 & 36,4 \\
\hline Nedidelis & 10 & 45,5 \\
\hline Vidutinis & 3 & 13,6 \\
\hline Vidutiniškai sunkus & 0 & 0 \\
\hline Sunkus & 1 & 4,5 \\
\hline
\end{tabular}


tyvinių funkcijų ypatumai šiose imtyse skiriasi (4 lentelè). Mūsų atliktame ir K. Morris su bendraautoriais (2012) aprašytame tyrime gautų bendro vidutinio ACE-III ir atskiru jo sričių suminių balų skaičius gerokai skiriasi nuo sveikų tiriamųjų gaunamų rezultatų. S. Hsieh ir kt. (2013), D. Fiedorova su kolegomis (2018), įvertinę sveikų tiriamujų kognityvines funkcijas, gavo panašius rezultatus, kurie parodè, jog asmenys, nepatyrę insulto, nepasižymi kognityvinių funkcijų sutrikimais. Tokie rezultatai atskleidžia, kad insultą patyrusių pacientų blogesnès kognityvinès funkcijos, negu sveikujų. Ne visi insultą patyrę pacientai pasižymi kognityvinių funkcijų sutrikimais, tačiau mūsų tyrimo rezultatai atskleidè, jog kognityvinès funkcijos sutrikusios net 81,8 proc. tiriamujų. Panašius rezultatus gavo K. Morris ir kt. (2012) atliktame tyrime, nustatę, kad 77,5 proc. pacientų po insulto patiria kognityvinių funkcijų sutrikimus. Kyla klausimas, ar literatūroje [2] nurodytas insultą patyrusių pacientų kognityvinių sutrikimų mastas yra tikslus ir atspindintis visą insultą patyrusių pacientų populiaciją.

Lyginant mūsų tyrime gautus insultą patyrusių pacientų ypatumus su gautais kituose tyrimuose, galima pastebėti, kad yra tiek panašumų, tiek skirtumų (4 lentelè). D. Fiedorovos su kolegomis (2018) gauti ACE-III rezultatai insultą patyrusių pacientų imtyje šiek tiek skiriasi nuo mūsų tyrime gautų rezultatų. Visų ACE-III sričių suminiai rezultatai D. Fiedorovos su kolegomis (2018) tyrime yra aukštesni, vadinasi, tiriamieji pasižymejjo geresnėmis kognityvinèmis funkcijomis. Tokiems rezultatams įtakos galèjo turèti skirtingi ịtraukimo ị tyrimą kriterijai. D. Fiedorova su kolegomis (2018) tyrime kviete dalyvauti insultą patyrusius pacientus, kurių MMSE įvertis buvo didesnis arba lygus 25 balams, t.y. neturinčius kognityvinių funkcijų sutrikimų, bei asmenis, kurie nepasižymėjo depresiškumu. Žinant, kad insultas sutrikdo kognityvines funkcijas iki 50 proc. pacientu [2], tokie ìtraukimo i tyrimą kriterijai gali nevisiškai tiksliai atspindèti insultą patyrusių pacientų kognityvinių funkcijų ypatumus. Lyginant mūsų tyrime gautus ir D. Fiedorovos su kolegomis (2018) atlikto tyrimo rezultatus, galima pastebèti, kad bendras ACE-III ịvertis skiriasi. Mūsų tyrime vidutinis bendras ACE-III įvertis rodo, kad insultą patyrusiems pacientams būdingi kognityvinių funkcijų sutrikimai (ribinis balas 82), o D. Fiedorovos su kolegomis (2018) gautas vidutinis bendras ACE-III ịvertis rodo, kad insultą patyrusiems pacientams kognityvinių funkcijų sutrikimai būdingi tik iš dalies, atsižvelgiant ị standartinị nuokrypį. Tokie skirtingi rezultatai rodo, kad insultą patyrusių pacientų kognityvinių funkcijų ypatumų atskleidimui turi reikšmès tiriamujų įtraukimo ị tyrimą kriterijai. Mūsų tyrimo rezultatai patvirtina K. Morris ir kt. (2012) tyrimo rezultatus, kuriame gauti panašūs rezultatai ne tik lyginant bendrą vidutinị ACE-III ịvertị, tačiau ir atskirų sričiu suminius rezultatus. Tame pačiame tyrime pasirinkti panašūs ị mūsų ịtraukimo ị tyrimą kriterijai. Mūsų ir K. Morris su bendraautoriais (2012) atliktų tyrimų rezultatai sutampa bei atskleidžia, kad insultą patyrusiems pacientams būdingi kognityvinių funkcijų sutrikimai, kurie pasireiškia pablogejjusia atmintimi, prastesniu žodiniu sklandumu bei prastesniais erdviniais gebejjimais.

Aptariant depresiškumo ypatumus insultą patyrusių pacientų grupeje galima pastebėti, kad PHQ-9 vidutiniai balai tyrimuose skiriasi. Panašiausius ị mūsų rezultatus gavo P. Dajpratham su kolegomis (2018), kurie parodè, kad insultą patyrusių pacientų vidutinis PHQ-9 įvertis yra 5,2 balo. Tai vienu balu mažesnis vidutinis ịvertis, nei gautas mūsų tyrime. Lyginant insultą patyrusių pacientų rezultatus su sveikų ti-

4 lentelė. ACE-III rezultatų palyginimas tarp insultu sergančių ir sveikų tiriamųjų

\begin{tabular}{|c|c|c|c|c|c|}
\hline \multirow[b]{2}{*}{ ACE-III rezultatai } & \multicolumn{5}{|c|}{ İvairių tyrèjų gauti rezultatai } \\
\hline & mūsų tyrimo & $\begin{array}{l}\text { D. Fiedorovos } \\
\text { ir kt. (2018) }\end{array}$ & $\begin{array}{l}\text { K. Morris } \\
\text { ir kt. (2012) }\end{array}$ & $\begin{array}{c}\text { S. Hsieh } \\
\text { ir kt. }(2013)\end{array}$ & $\begin{array}{c}\text { D. Fiedorovos } \\
\text { ir kt. (2018) }\end{array}$ \\
\hline Tiriamieji & \multicolumn{3}{|c|}{ po insulto } & \multicolumn{2}{|c|}{ sveikieji } \\
\hline Imtis & $\mathrm{n}=22$ & $\mathrm{n}=84$ & $\mathrm{n}=40$ & $\mathrm{n}=25$ & $\mathrm{n}=72$ \\
\hline $\begin{array}{l}\text { Dėmesio srities vidutinis } \\
\text { ivvertis }\end{array}$ & $15,27 \pm 2,03$ & $17,4 \pm 1,03$ & $15,3 \pm 2,2$ & $17,4 \pm 1,2$ & $17,43 \pm 0,85$ \\
\hline $\begin{array}{l}\text { Atminties srities vidutinis } \\
\text { ivvertis }\end{array}$ & $14,45 \pm 5,05$ & $19,48 \pm 4,59$ & $15,7 \pm 4,2$ & - & $21,68 \pm 3,12$ \\
\hline $\begin{array}{l}\text { Žodinio sklandumo srities } \\
\text { vidutinis įvertis }\end{array}$ & $6,27 \pm 2,62$ & $9,75 \pm 2,85$ & $7,1 \pm 2,9$ & - & $11,53 \pm 1,84$ \\
\hline Kalbos srities įvertis & $19,5 \pm 3,43$ & $25,32 \pm 1,21$ & - & $25,6 \pm 0,6$ & $25,21 \pm 1,31$ \\
\hline $\begin{array}{l}\text { Erdvinių gebejimų srities } \\
\text { vidutinis įvertis }\end{array}$ & $12,91 \pm 2,49$ & $14,88 \pm 1,79$ & $11,7 \pm 4$ & $15,6 \pm 0,6$ & $15,4 \pm 0,85$ \\
\hline $\begin{array}{l}\text { Bendras ACE-III vidutinis } \\
\text { ivvertis }\end{array}$ & $68,41 \pm 11,82$ & $86,19 \pm 9,88$ & $70,9 \pm 14$ & $95,4 \pm 3,3$ & $91,26 \pm 5,28$ \\
\hline
\end{tabular}


riamųjų grupe galima pastebėti, kad PHQ-9 vidutinis sveiku tiriamųu įvertis yra mažesnis, nei patyrusių insultą. Apibendrinant pateiktus duomenis galima pastebèti, kad insultą patyrusiems pacientams būdingas didesnis depresiškumas.

Analizuojant depresiškumo paplitimą insultą patyrusių pacientų imtyje, galima pastebẻti, kad mūsų tyrime (3 lentelè) net 63,6 proc. pacientų būdingas depresiškumas $(\mathrm{PHQ}>4)$. Tokie rezultatai nesutampa su literatūroje minimu po insulto atsiradusios depresijos paplitimu, kuris siekia 30 procentų. L. E. Fournier su kolegomis (2019), atlikę tyrimą su insultą patyrusiais pacientais, atskleidè, kad depresiškumas būdingas 30-46 proc. pacientų, priklausomai nuo praejjusio laiko po insulto. Toks depresiškumo paplitimas tarp insultą patyrusių pacientų rodo, kad svarbu ịvertinti šių pacientų depresiškumą iškart po insulto ir stebèti, kaip jis keičiasi bėgant laikui. Analizuojant insultą patyrusių pacientų vidutiniško ar sunkaus depresiškumo paplitimo mastą galima pastebèti, kad mūsų tyrime toks depresiškumo išreikštumas būdingas beveik 20 proc. insultą patyrusių pacientų. Panašius rezultatus gavo ir P. Dajpratham su kolegomis (2018). Tokie rezultatai gali būti gaunami dèl to, kad literatūroje nurodoma, jog didesnis depresiškumas būdingas jaunesniems insultą patyrusiems pacientams, o mūsų tyrime didžiają dalį sudare vyresnio amžiaus tiriamieji. Tyrimuose aprašomas skirtingas insultą patyrusių pacientų depresiškumo paplitimas ir lygis gali atsirasti dẻl įtraukimo ị tyrimą kriterijų skirtumų ir nepakankamai žinomų veiksnių, kurie lemia depresijos atsiradimą po insulto.

Mūsų tyrime siekta atskleisti insultą patyrusių pacientų saviveiksmingumo ypatumus. Gautieji rezultatai parodè pakankamai aukštus insultą patyrusių pacientų saviveiksmingumo įverčius ( $M=40,86 \pm 8,01)$. Panašius rezultatus gavo ir kiti tyrèjai, matavę insultą patyrusių pacientų saviveiksmingumą SSEQ skale [15]. Yra duomenų, kad sèkmingos reabilitacijos metu insultą patyrusių pacientų saviveiksmingumas laipsniškai didèja [16]. Kita vertus, tokie rezultatai gali reikšti, kad insultą patyrusių pacientų saviveiksmingumui išmatuoti reikalingi metodai turètų apimti daugiau aspektų, nes įvykus insultui, reikia pastangų ir tikèjimo savo jëgomis įveikti užduotis daugelyje gyvenimo sričių. Aukšti insultą patyrusių pacientų saviveiksmingumo įverčiai mūsų ir kituose nagrinètuose tyrimuose gali būti gaunami dèl to, kad juose dalyvauti dažniausiai kviečiami pakankamai geros fizinès būklès tiriamieji, galintys suprasti užduodamus klausimus ir atsakyti i juos. Lieka neaišku, koks saviveiksmingumo lygmuo yra kitos dalies insultą patyrusių pacientų, kurie dažniausiai nepasiekiami ir nekviečiami dalyvauti tyrime dèl patiriamos afazijos, sunkių motorikos ir kognityvinių funkcijų sutrikimų.

\section{Išvados}

1. Insultą patyrusių pacientų labiausiai pažeistos kognityvinès funkcijos yra atmintis ir žodinis sklandumas.

2. Kognityvinių funkcijų sutrikimai būdingi 81,8 proc. insultą patyrusių pacientų.

3. Depresiškumas būdingas 63,6 proc. insultą patyrusių pacientų.

4. Insultą patyrę pacientai pasižymi gana aukštu saviveiksmingumu.

\section{Literatūra}

1. Tatemichi TK, Desmond DW, Stern Y, Paik M, Sano M, Bagiella E. Cognitive impairment after stroke: frequency, patterns, and relationship to functional abilities. J Neurol Neurosurg Psychiatry 1994;57(2):202-207.

https://doi.org/10.1136/jnnp.57.2.202

2. Pendlebury ST, Rothwell PM. Prevalence, incidence, and factors associated with pre-stroke and post-stroke dementia: a systematic review and meta-analysis. Lancet Neurol 2009;8(11):1006-1018.

https://doi.org/10.1016/S1474-4422(09)70236-4

3. Sun JH, Tan L,Yu JT. Post-stroke cognitive impairment: epidemiology, mechanisms and management. Ann Transl Med 2014;2(8):80.

4. Jehkonen M, Laihosalo M, Keetuenen JE. Impact of neglect on functional outcome after storke: a review of methodological issues and recent research findings. Restor Neurol Neurosci 2006;24(4-6):209-215.

5. Kim JS, Choi-Kwon S. Poststroke depression and emotional incontinence: correlation with lesion location. Neurology 2000;54(9):1805-1810.

https://doi.org/10.1212/WNL.54.9.1805

6. Folstein MF, Maiberger R, McHugh PR. Mood disorder as a specific complication of stroke. J Neurol Neurosurg Psychiatry 1977;40(10):1018-1020.

https://doi.org/10.1136/jnnp.40.10.1018

7. Ayerbe L, Ayis S, Wolfe CD, Rudd AG. Natural history, predictors and outcomes of depression after stroke: systematic review and meta-analysis. Br J Psychiatry 2013;202(1),14-21.

https://doi.org/10.1192/bjp.bp.111.107664

8. Hussein A, Idris I, Abbasher M, Abbashar H, Abbasher KMA. Post stroke depression. J Neurol Sci 2019; 405, 70. https://doi.org/10.1016/j.jns.2019.10.349

9. Jones F, Riazi A. Self-efficacy and self-management after stroke: a systematic review. Disabil Rehabil 2011;33(10),797-810. https://doi.org/10.3109/09638288.2010.511415

10. Bandura A. Exercise of personal and collective efficacy in changing societies. Self-efficacy in changing societies. Cambridge University Press 1995;1-45.

https://doi.org/10.1017/CBO9780511527692.003

11. Hsieh S, Schubert S, Hoon C, Mioshi E, Hodges JR. Validation 
of the Addenbrooke's cognitive examination III in frontotemporal dementia and Alzheimer's disease. Dement Geriatr Cogn Disord 2013;36(3-4):242-250.

https://doi.org/10.1159/000351671

12. Lees R, Selvarajah J, Fenton C, Pendlebury ST, Langhorne P, et al. Test accuracy of cognitive screening tests for diagnosis of dementia and multidomain cognitive impairment in stroke. Stroke, 2014;45(10):3008-3018.

https://doi.org/10.1161/STROKEAHA.114.005842

13. Spitzer RL, Kroenke K, Williams JB, Löwe B. A brief measure for assessing generalized anxiety disorder: the GAD-7. Arch Intern Med 2006;166(10):1092-1097.

https://doi.org/10.1001/archinte.166.10.1092

14. Kroenke K, Spitzer RL. The PHQ-9: a new depression diagnostic and severity measure. Psychiatric Annals 2002;32(9):509515.

https://doi.org/10.3928/0048-5713-20020901-06

15. Jones F, Partridge C, Reid F. The stroke self-efficacy questionnaire: measuring individual confidence in functional performance after stroke. J Clin Nurs 2008;17(7B):244-252. https://doi.org/10.1111/j.1365-2702.2008.02333.x

16. Riazi A, Aspden T, Jones F. Stroke self-efficacy questionnaire: a rasch-refined measure of confidence post stroke. J Rehabil Med 2014;46(5):406-412. https://doi.org/10.2340/16501977-1789

17. Morris K, Hacker V, Lincoln NB. The validity of the Addenbrooke's cognitive examination-revised (ACE-R) in acute stroke. Disabil Rehabil 2012;34(3):189-195. https://doi.org/10.3109/09638288.2011.591884

18. Fiedorova D, Krulova P, Ressner P, Jaremova V, Slonkova J, et al. Addenbrooke's cognitive examination in nondemented patients after stroke. Neuropsychiatry 2018;8(2),505-512. https://doi.org/10.4172/Neuropsychiatry.1000372

19. Dajpratham P, Pukrittayakamee P, Atsariyasing W, Wannarit K, Boonhong J, Pongpirul K. The validity and reliability of the
PHQ-9 in screening for post-stroke depression. BMC Psichiatry 2020;291(20).

https://doi.org/10.1186/s12888-020-02699-6

20. Fournier LE, Beauchamp JES, Zhang X, Bonojo E, Love M, et al. Assessment of the progression of poststroke depression in ischemic stroke patients using the Patient Health Questionnaire-9. J Stroke Cerebrovasc Dis 2020;104561.

https://doi.org/10.1016/j.jstrokecerebrovasdis.2019.104561

\section{CHARACTERISTICS OF COGNITIVE FUNCTIONS, DEPRESSION AND SELF-EFFICIENCY IN STROKE PATIENTS \\ J. Janavičiūtė, L. Šinkariova}

Keywords: stroke patients, cognitive function, depression, self-efficacy.

Summary

Stroke patients - a specific sample characterized by a variety of post-stroke difficulties: cognitive impairment, depression, and decreased self-efficacy. All of these difficulties pose challenges to their daily functioning. The aim of the study is to evaluate the peculiarities of cognitive functions, depression and self - efficacy in stroke patients. The study included 22 stroke patients ranging in age from 61 to 89 years $(M=78.09 ; \mathrm{SD}=8.6)$. The subjects were asked sociodemographic questions. Cognitive function in stroke patients was measured via Addenbrooke's Cognitive Examination III. The Patient Health Questionnaire was used to measure depression, and The Stroke Self-Efficacy Questionnaire was used for self-efficacy evaluation. The results of the study revealed that 81.8 percent. stroke patients experiece cognitive impairment. Also, depression was indentified for 63.6 percent. stroke patients. Stroke patients have a sufficiently high self-efficacy.

Correspondence to: janaviciute.jovita@gmail.com

Gauta 2020-06-18 